\title{
A Comparative Analysis of Experiential Education and Student Development: Does the Type of Service Matter?
}

\author{
Lori Simons ${ }^{1, *}$, Lawrence Fehr ${ }^{1}$, Nancy Blank ${ }^{2}$, David Fernandez ${ }^{1}$, Denise Georganas ${ }^{1}$, Jessica Padro ${ }^{1}, \&$ Verda \\ Peterson $^{1}$ \\ ${ }^{1}$ Psychology Department, Widener University, Chester, PA 19013, USA \\ ${ }^{2}$ Criminal Justice Department, Widener University \\ *Corresponding author: Psychology Department, Widener University, Chester, PA 19013, USA \\ E-mail: lorgold@aol.com
}

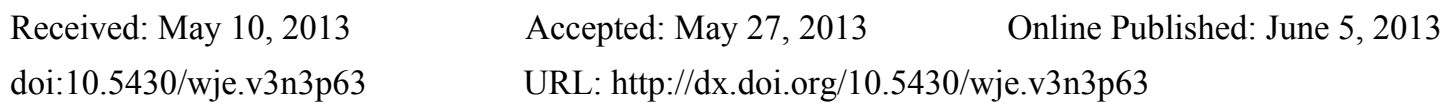

\begin{abstract}
A comparative analysis was conducted on student attitudes and skills among student interns, academic-based service-learners, and cultural-based service-learners. Students did not differ in scores at the beginning of the semester, but by the end of the term student interns had higher multicultural awareness and intercultural relationship scores and lower racial and civic attitude scores than did cultural-based service-learners. Field supervisors also appraised student interns as having a better ability to develop relationships with professionals at placement sites than service-learners. The consistency of data from field supervisors and students suggest that the alignment between the course content and the service activity is associated with student development and learning.
\end{abstract}

Keywords: service-learning; practicum; internship; diversity

\section{Introduction}

Educators propose that experiential education is a transformative pedagogy that illuminates the racial, economic and social disparities in the community and engages students in service activities designed to address these problems (Mitchell, 2010). Experiential education refers to a broad range of academic endeavors, from service-learning and community service, to practica, and internships (Association for Experiential Education, 2011). Academic-based service-learning (ABSL) combines academic study with community service (Eyler, 2002), while cultural-based service-learning (CBSL) integrates race, culture, and class concepts with both discipline content and service activities (Sperling, 2007). Service-learning differs from practica and internships (i.e., career-related work for academic credit) in that service activities are designed to benefit both students and recipients (Sigmon, 1996).

The few studies that have systematically studied the impact of practicum and internship on student attitude-formation suggest that the learning aspect is the transformation of student attitudes (Sweitzer \& King, 2009). Astin and Sax (1998) conducted a longitudinal survey study with 3,450 freshman enrolled at 42 institutions with federally funded community service programs and found that the amount of time devoted to providing service in a community-based program was related to students greater understanding of problems in the community. Aldas, Crispo, Johnson, and Price (2010) summarized data from the National Survey of Student Engagement (NSSE) at Wagner College and similarly found that practica and internships enhance students' ability to contribute to the welfare of the community. Wagner college student ratings were significantly higher compared to students at peer institutions and those students at comprehensive institutions.

The idea behind the transformational perspective is that student participation in community service challenges preconceived assumptions and teaches them to reformulate their attitudes. However, research on service-learning counters this perspective and suggests that some students change while other students retain their preconceived assumptions about social justice issues in the community (Cipolle, 2010). Conley and Hamlin (2009) conducted a case analysis on reflections from five students enrolled in a semester-long, first-year seminar at an inner-city college. These researchers found that all five participants changed their thoughts about power and privilege and gained an 
understanding of the conditions that lead to inequities in society. Yeh (2010) also conducted a content analysis on participant responses. In this study, a semi-structured interview was administered to a purposeful sample of 10 students enrolled in service-learning courses at two research universities. Her findings indicate that participants gain awareness and understanding of the disenfranchised communities in which they worked. McKay and Estrella (2008) identified common themes gathered with open-ended questions from 43 students enrolled in 20 service-learning courses at a large metropolitan university, and discovered that students improved their comprehension of social justice concepts and interest in community service.

In contrast, Boyle-Baise and Langford (2004) conducted a case study with eight students enrolled in a social justice seminar and observed that students acquired limited information about their own privilege from the beginning to the end of service. Green (2001) also detected that students were resistant to recognize how racial privilege influences interactions with recipients after analyzing response papers from 14 students in a social justice seminar. Dunlap, Scoggin, Green, and Davi (2007) suggest that students retain their stereotypes through participation in service activities that reinforce the power dynamic between White students and service recipients. Experiential education may serve as a transformative pedagogy that assists students acquire an understanding of social justice issues in the community, but only if they are required to examine the relationship between power and privilege in both the course content and the service context. Additional research is necessary to disentangle the effects from the different types of experiential activities on student development and learning. The goal of this study was to compare differences in student learning outcomes (i.e., attitudes, skills) for students enrolled in ABSL, CBSL, and practicum/internship courses. This study was guided by two research questions:

(1). Do student interns make greater improvements in their personal development as measured by increases in their civic, diversity, racial, and social justice attitudes, and multicultural awareness, knowledge, and skills than academicand cultural-based service-learners from the beginning to the end of the term?

(2). Do field supervisors make higher ratings of attitudes and skills for student interns compared to service-learners?

\section{Method}

\subsection{Participants}

Student Participants. College students from a private teaching university in a northern metropolitan area completed a pretest and a posttest survey. Data were gathered from 101 undergraduate students enrolled in academic-based service-learning (ABSL) $(\mathrm{n}=45)$, cultural-based service-learning $(\mathrm{CBSL})(\mathrm{n}=17)$, and practicum/internship $(\mathrm{n}=39)$ courses during the 2009-2010 academic year. Most students identified themselves as White (70\%) and female (74\%) as shown in Table 1.

Table 1: Demographic Characteristics of Student Interns and Service-Learners

\begin{tabular}{llll}
\hline Characteristic & $\begin{array}{l}\text { Groups } \\
\text { Academic-Based } \\
\text { Service-Learners } \\
\%\end{array}$ & $\begin{array}{l}\text { Cultural-Based } \\
\text { Service-Learners } \\
\%\end{array}$ & $\begin{array}{l}\text { Student Interns } \\
\%\end{array}$ \\
& & $\underline{0}$ & \\
\hline Gender & 18 & 31 & 22 \\
Male & 82 & 68 & 77 \\
Female & & & $21.50(1.10)$ \\
Age (M, SD) & $19.52(1.24)$ & $19.76(1.03)$ & \\
& & & 08 \\
Race & 16 & 18 & 73 \\
African-American & 81 & 82 & 15 \\
White & 03 & --- & 02 \\
Biracial/Multiracial & --- & - & \\
I do not wish to answer & & & --- \\
Year & 42 & --- & - \\
Freshman & 24 & 65 & \\
Sophomore & & & \\
\hline
\end{tabular}




\begin{tabular}{llll}
\hline Junior & 34 & 24 & 18 \\
Senior & --- & 11 & 82 \\
& & & \\
Major & 11 & 61 & 100 \\
Psychology & 83 & --- & --- \\
Education & 02 & 23 & --- \\
Nursing & 02 & 11 & --- \\
Social Work & 02 & 05 & \\
Undecided & & & \\
& & 56 & 10 \\
Placements & 88 & 33 & 03 \\
Public Elementary School & 08 & --- & 15 \\
Public High School & 04 & --- & 15 \\
Child Care/Day Care & --- & --- & 30 \\
Mental Health Center & --- & 11 & 12 \\
Drug and Alcohol Center & --- & & 32 \\
Rehabilitation Center & --- & 12 & \\
Community-Based Program & & & \\
Additional Service Course & 48 & & \\
\hline
\end{tabular}

Field Supervisors. Preceptor teachers from one of three public schools located in an urban area and agency supervisors from community-based organizations completed an assessment on each student with whom they were paired for the academic semester. Most field supervisors identified themselves as either White (70\%) or Black (30\%) and female (82\%). Data was also gathered on 31 agency supervisors who were eligible to participate in the interview (response rate $=100 \%$ ). Ninety percent of agency supervisors and all $(100 \%)$ of preceptor teachers had a four-year degree. Preceptor teachers' average length of teaching in the district was 17 years and their average length of teaching in their current position was 11 years.

\subsection{Content}

Academic-Based Service-Learning. The Educational Psychology: Early Learners is a three-credit course intended to prepare students to work with children at a public school and requires a field placement (i.e., service-learning) to meet the National Council Accreditation for Teacher Education and the Pennsylvania Department of Education standards. Topics covered in this course include measurement theory, achievement tests, developmental, behavioral, and motivational theories, and diversity in school settings. Students are required to complete 15 hours of service in which they tutor or mentor children who differ from them in race, ethnicity, and socioeconomic status. Students also are required to answer structured reflection questions before, during, and after service. The structured reflection questions require students to connect the service context to the course content. Students are further required to complete a multicultural paper. Students watch and summarize a diversity film (i.e., Stand and Deliver, Dangerous Minds), describe the main character, compare and contrast the demographic characteristics of this character to the child with whom they were paired at the school, and apply psychological theories to explain the development of the main character. Finally, students take part in a closing reception at the service placement and reflect on what they learned throughout the semester.

Cultural-Based Service-Learning. The multicultural psychology is a three-credit course that fulfills a distribution requirement in the psychology and African and African American Studies curricula. Topics covered in this course include multicultural psychology, stereotypes, ageism, sexism, classism, racism, racial identity development, oppression and privilege, and cultural competence. Students are required to complete 15 hours of service in which they assist the teacher in his/her classroom and either tutor or mentor children who differ from them at one of two elementary public schools. Students may work with high school students on their senior projects to fulfill the service requirement; the university and high school students differ racially and culturally. Students are also required to complete structured reflection questions after each class and service experience so they can critically analyze their thoughts and feelings about race and class concepts within the course and service context over the semester. In addition, students are required to complete a multicultural observation, a multicultural movie review, and an intercultural interview. The multicultural observation requires students to attend an activity associated with a culture 
or ethnic group that is distinctively different from them and then they write a short description about it. The multicultural movie review requires students to watch a diversity film (i.e., Crash, Save the Last Dance), apply diversity theories to explain the main theme of the movie, and describe what they did or did not learn in terms of racial identity development and multicultural competence (i.e., awareness, knowledge, \& skills). The intercultural interview paper requires students to interview two individuals who differ in one cultural characteristic, compare and contrast their responses, and integrate theory and research to explain their interview findings. The course ends with a social network activity and a reflective discussion about how student concerns about taking this class have changed throughout the semester.

Practicum/Internship. The practicum/internship program is a sequential model comprised of a professional development seminar and a practicum that fulfills distribution electives in the psychology curriculum. The professional development seminar is designed as a one-credit course in which students learn about the logistics of setting up a practicum. After successful completion of this course, students enroll in a practicum or an internship. The practicum introduces students to field work in social service agencies or other appropriate settings, while the internship provides advanced training related to field work and allows them to gain extensive "real world" experience (American Psychological Association, 2005). Students work under the supervision of the field supervisor at the placement for 100 to 200 hours and meet regularly with a faculty member who serves as a practicum advisor (i.e., a faculty member who has experience in their area of interest). The practicum advisor guides students on the academic components of the course that include documentation of field hours, a daily journal in which they describe and reflect on what they learned at the placement, and a research paper. The research paper requires students to integrate psychological theory with scholarly research relevant to their placement and practical aspects of practicum (i.e., case reflection, ethical standards). Students enrolled in an internship are required to complete an extensive research paper and the academic components of a practicum.

\subsection{Measures}

A Demographic Questionnaire, developed by the researchers, was used to gather information on gender, race, age, GPA, area of study, and year in school.

The Civic Attitudes and Skills Questionnaire (CASQ), developed by Moely, Mercer, Ilustre, Miron, and McFarland (2002), assessed civic attitudes and skills. The CASQ, an 84-item self-report questionnaire, yields scores on six scales: 1. Civic Action (respondents evaluate their intentions to become involved in the future in some community service); 2. Interpersonal and Problem-Solving Skills (respondents evaluate their ability to listen, work cooperatively, communicate, make friends, take the role of the other, think logically and analytically, and solve problems); 3. Political Awareness (respondents evaluate their awareness of local and national events and political issues); 4. Leadership Skills (respondents evaluate their ability to lead); 5. Social Justice Attitudes (respondents rate their agreement with items expressing attitudes concerning the causes of poverty and misfortune and how social problems can be solved); and 6 . Diversity Attitudes (respondents describe their attitudes toward diversity and their interest in relating to culturally different people. Internal consistencies for each scale reported by Moely et al. (2002) ranged from .69 to .88, and test-retest reliabilities for each scale ranged from .56 to .81 . This scale has a strong level of reliability $(\alpha=.93)$ among the current student group.

The Multicultural Counseling Inventory-for Educators (MCI), developed by Sodowsky, Taffe, Gutkin, and Wise (1994) measured cultural competence on four scales: 1. Awareness (respondents assess the degree of their cultural awareness); 2. Knowledge (respondents assess the degree of their cultural knowledge); 3. Skills (respondents assess the degree of their cultural skills); and 4. Relationship (respondents assess their interactional process and relationships with others who differ from them). Cronbach's coefficient alpha for each scale ranged from .68 to .80 . This scale has a strong level of reliability $(\alpha=.81)$ among the current student group.

The Modern Racism Scale (MRS), developed by McConahay (1986), assessed the extent to which individuals have negative attitudes toward Blacks. Seven items were added together to produce a full-scale score. Reliability for this scale is strong $(\mathrm{r}=.81)$. The MRS scale was modified to measure prejudice toward minorities by changing the term "Blacks" to "Minorities" in the questions. This scale has a strong level of reliability $(\alpha=.79)$ among the current student group.

The Social Science Division Field Evaluation of Student Internship Checklist measured field supervisors' satisfaction with the student intern. Field supervisors assessed each intern's performance on knowledge, skills, and attitudes on a checklist with six categories ranging from "1" not applicable to "6" superior. Field supervisors also answered five open-ended were: (1). Describe the tasks the intern has been assigned, (2). What knowledge and skills has the intern acquired as a result of the work experience in your organization, (3). Has the intern made any outstanding 
contribution to the work of your organization, (4). If you had the opportunity would you hire this intern for a position, and (5). Which grade would you assign for the intern's performance? This scale has a moderate level of reliability $(\alpha=.82)$.

\subsection{Procedure}

An explanatory mixed methods design was used to collect data on undergraduate students and field supervisors who participated in an experiential education program (Creswell, 2005). All of the students completed an informed consent form and a survey that included the Civic Attitudes and Skills Questionnaire (CASQ) (Moely et al., 2002), the Modern Racism Scale (McConahay, 1983), and the Multicultural Counseling Inventory (MCI) (Sodowsky et al., 1994). Students completed the survey, placed it in a coded, confidential envelope and gave it directly to the researcher. Students were required to complete this survey again after they completed their required hours of service (i.e., 15 hours for service-learners, 200 for interns). Surveys took about 45 minutes to complete. In addition, students were given the field evaluation of student internship checklist and gave it to their field supervisor. Field supervisors completed this form at their own pace, reviewed this information with the student and sent it to the researcher by the end of the term. The field supervisor response rate was $95 \%$.

\section{Results}

\subsection{Quantitative Analysis}

A repeated measures analyses of variance with planned orthogonal contrasts were conducted to evaluate student development among academic-based service-learners (ABSL), cultural-based service-learners (CBSL), and student interns from the beginning to the end of the semester. The pretest and posttest scores for CASQ, MRS, and MCI were used as dependent variables, and the type of service was the independent variable. There was significant Group $x$ Time interaction effects for the CASQ, MRS, and MCI. Student interns had higher multicultural awareness and intercultural relationship scores than cultural-based service-learners by the end of the term as shown in Tables 2 and 3. An independent t-test was conducted to measure differences on field supervisors' views of student interns $(\mathrm{n}=34)$ and service-learners $(n=40)$. Field supervisors appraised students interns $(\chi=4.68)$ as having a better ability to develop relationships with coworkers $t(70)=-2.50, p<.05$ than service-learners $(\chi=3.75)$. Most field supervisors appraised student interns and service-learners as good or superior in their ability to learn as shown in Table 4.

Table 2: Mean Scores, Standard Deviations, and F Ratios for Pre- and Posttest Scores for Personal Development and Cultural Competence as a Function of Service Condition

\begin{tabular}{|c|c|c|c|c|c|c|c|}
\hline \multirow[b]{2}{*}{ Measure } & \multicolumn{2}{|l|}{ Pretest } & \multicolumn{2}{|c|}{$\begin{array}{l}\text { Time Points } \\
\text { Posttest }\end{array}$} & \multicolumn{3}{|c|}{ F ratios } \\
\hline & M & SD & M & SD & Group & Time & $\begin{array}{l}\text { Time } x \\
\text { Group }\end{array}$ \\
\hline \multicolumn{8}{|c|}{ Civic Attitudes and Skills Questionnaire (CASQ) } \\
\hline Civic & & & & & $16.08 * * *$ & $41.51 * * *$ & $19.09 * * *$ \\
\hline \multicolumn{8}{|l|}{ Action } \\
\hline Student & 32.90 & 4.49 & 31.14 & 3.87 & & & \\
\hline Interns & 34.44 & 8.26 & 33.10 & 4.20 & & & \\
\hline ABSL & 46.23 & 4.67 & 33.00 & 4.56 & & & \\
\hline CBSL & 36.92 & 8.39 & 32.46 & 4.23 & & & \\
\hline \multicolumn{8}{|l|}{ Total } \\
\hline Problem- & & & & & $4.35^{*}$ & .31 & 1.21 \\
\hline Solving & 44.31 & 3.80 & 43.21 & 4.02 & & & \\
\hline Student & 41.86 & 3.60 & 40.89 & 4.23 & & & \\
\hline Interns & 40.13 & 3.87 & 41.20 & 4.82 & & & \\
\hline ABSL & 42.19 & 3.98 & 41.66 & 4.37 & & & \\
\hline \multicolumn{8}{|l|}{ CBSL } \\
\hline \multicolumn{8}{|l|}{ Total } \\
\hline Leadersh & & & & & .43 & 1.95 & .37 \\
\hline ip & & & 15.04 & & & & \\
\hline Student & 15.67 & 2.81 & 14.43 & 2.10 & & & \\
\hline
\end{tabular}




\begin{tabular}{llllllll}
\hline Interns & 15.23 & 2.48 & 15.00 & 2.35 & & \\
ABSL & 15.05 & 2.46 & 14.76 & 2.26 & & \\
CBSL & 15.32 & 2.55 & & 2.24 & & \\
Total & & & & & & \\
& & & & & $4.10^{*}$ & .69 \\
Diversity & & & & & & \\
Student & 20.04 & 2.29 & 19.33 & 2.49 & & \\
Interns & 18.46 & 3.33 & 17.50 & 2.60 & & \\
ABSL & 19.23 & 3.07 & 19.82 & 5.36 & & \\
CBSL & 19.14 & 3.01 & 18.64 & 3.57 & & \\
Total & & & & & & \\
& & & & & $7.74^{* *}$ & \\
Social & & & & & & \\
Justice & & & & & & \\
Student & 31.09 & 3.76 & 29.80 & 3.82 & & \\
Interns & 28.22 & 3.34 & 28.29 & 3.82 & & \\
ABSL & 31.92 & 3.79 & 32.00 & 4.20 & & \\
CBSL & 30.03 & 3.89 & 29.64 & 4.14 & & \\
Total & & & & & & \\
\hline
\end{tabular}

Note. ${ }^{1}$ Differential change by service-learners, reflected in an interaction of Group by Time, at ${ }_{* * *} \mathrm{p}<.001$.ANCOVA $\mathrm{F}$ ratios are Wilk's approximation for Group X Time interactions.

${ }^{2}$ Differential change as a function of group, ${ }^{*} \mathrm{p}<.05,{ }^{* * *} \mathrm{p}<.001 .{ }^{3}$ Differential change as a function of time, $* * * \mathrm{p}<.001$.

Table 2 (continued): Mean Scores, Standard Deviations, and F Ratios for Pre- and Posttest Scores for Personal Development and Cultural Competence as a Function of Service Condition

\begin{tabular}{|c|c|c|c|c|c|c|c|}
\hline \multirow[b]{3}{*}{ Measure } & \multicolumn{4}{|c|}{ Time Points } & \multirow{2}{*}{\multicolumn{3}{|c|}{ F ratios }} \\
\hline & \multirow{2}{*}{$\begin{array}{l}\text { Pretest } \\
\mathrm{M}\end{array}$} & \multicolumn{3}{|c|}{ Posttest } & & & \\
\hline & & SD & $\mathrm{M}$ & SD & \multirow{2}{*}{$\frac{\text { Group }}{49.59^{* * *}}$} & \multirow{2}{*}{$\frac{\text { Time }}{78.56^{* * *}}$} & $\begin{array}{l}\text { Time } \mathrm{x} \\
\text { Group }\end{array}$ \\
\hline \multicolumn{5}{|c|}{ Modern Racism Scale (MRS) } & & & $53.15 * * *$ \\
\hline Student Interns & 16.36 & 2.73 & 17.59 & 2.70 & & & \\
\hline ABSL & 17.50 & 3.04 & 17.46 & 2.76 & & & \\
\hline CBSL & 16.94 & 2.74 & 28.88 & 3.07 & & & \\
\hline Total & 17.00 & 2.87 & 20.31 & 5.66 & & & \\
\hline \multicolumn{8}{|c|}{ Multicultural Counseling Inventory (MCI) } \\
\hline Awareness & & & & & $17.25^{* * *}$ & $24.57 * * *$ & $22.30 * * *$ \\
\hline Student Interns & 26.27 & 3.92 & 25.38 & 4.29 & & & \\
\hline ABSL & 23.59 & 3.87 & 24.27 & 5.03 & & & \\
\hline CBSL & 23.75 & 3.51 & 14.87 & 2.57 & & & \\
\hline Total & 24.50 & 3.92 & 21.94 & 6.14 & & & \\
\hline Knowledge & & & & & $3.97 *$ & 2.07 & 1.75 \\
\hline Student Interns & 22.80 & 3.39 & 22.55 & 3.37 & & & \\
\hline ABSL & 22.34 & 3.36 & 22.53 & 4.30 & & & \\
\hline CBSL & 21.64 & 2.73 & 19.00 & 2.98 & & & \\
\hline Total & 22.33 & 3.21 & 21.71 & 3.97 & & & \\
\hline Skills & & & & & $12.97 * * *$ & .34 & $23.30 * * *$ \\
\hline Student Interns & 18.30 & 1.65 & 22.45 & 2.23 & & & \\
\hline ABSL & 18.43 & 1.72 & 17.73 & 2.56 & & & \\
\hline
\end{tabular}




$\begin{array}{lllll}\text { CBSL } & 21.42 & 2.50 & 18.71 & 2.61 \\ \text { Total } & 19.12 & 2.30 & 19.63 & 3.22\end{array}$

\begin{tabular}{llllllll}
\hline Relationships & & & & & $21.49^{* * *}$ & $17.45^{* * *}$ & $14.47^{* * *}$ \\
Student Interns & 24.61 & 3.77 & 24.27 & 3.49 & & & \\
ABSL & 22.92 & 3.48 & 23.03 & 2.65 & & & \\
CBSL & 23.06 & 2.12 & 16.20 & 1.37 & & & \\
Total & 23.46 & 3.33 & 21.70 & 4.19 & & &
\end{tabular}

Note. ${ }^{1}$ Differential change by service-learners, reflected in an interaction of Group by Time, at $* * * \mathrm{p}<.001$.ANCOVA F ratios are Wilk's approximation for Group X Time interactions. ${ }^{2}$ Differential change as a function of group, ${ }^{* * *} \mathrm{p}<.001,{ }^{*} \mathrm{p}<.05 .{ }^{3}$ Differential change as a function of time, ${ }^{* * *} \mathrm{p}<.001$.

Table 3: Mean Scores on Personal Development and Cultural Competence Measures as a Function of Service Condition

\begin{tabular}{|c|c|c|c|c|c|c|c|}
\hline \multirow[b]{4}{*}{ Measures } & \multicolumn{6}{|c|}{ Groups } & \multirow[b]{4}{*}{ Post hoc } \\
\hline & \multirow{2}{*}{\multicolumn{2}{|c|}{$\begin{array}{l}\text { (1) } \\
\text { Student Interns }\end{array}$}} & \multirow{2}{*}{\multicolumn{2}{|c|}{$\begin{array}{l}\text { (2) } \\
\text { ABSL }\end{array}$}} & \multirow{2}{*}{\multicolumn{2}{|c|}{ CBSL $^{(3)}$}} & \\
\hline & & & & & & & \\
\hline & \multicolumn{2}{|c|}{$\underline{\mathrm{M}} \underline{\mathrm{SD}}$} & \multicolumn{2}{|c|}{$\underline{\mathrm{M}} \underline{\mathrm{SD}}$} & \multicolumn{2}{|c|}{$\underline{\mathrm{M}} \quad \underline{\mathrm{SD}}$} & \\
\hline \multicolumn{8}{|l|}{ CASQ } \\
\hline Civic Action & 31.14 & 3.87 & 33.10 & 4.20 & 33.00 & 4.56 & $3>1$ \\
\hline Problem Solving & 43.21 & 4.02 & 40.89 & 4.23 & 41.20 & 4.82 & $1>2,3$ \\
\hline Leadership & 15.04 & 2.10 & 14.43 & 2.35 & 15.00 & 2.26 & $1=2=3$ \\
\hline Diversity & 19.33 & 2.49 & 17.50 & 2.60 & 19.82 & 5.36 & $3>2$ \\
\hline Social Justice & 29.80 & 3.84 & 28.29 & 3.89 & 32.00 & 4.20 & $3>2$ \\
\hline MRS & 15.59 & 2.70 & 17.46 & 2.76 & 28.82 & 3.07 & $3>1$ \\
\hline \multicolumn{8}{|l|}{ MCI } \\
\hline Awareness & 25.38 & 4.29 & 24.27 & 5.03 & 14.87 & 2.57 & $1>3$ \\
\hline Knowledge & 22.55 & 3.37 & 22.53 & 4.30 & 19.00 & 2.98 & $1>3$ \\
\hline Skills & 22.45 & 2.23 & 17.73 & 2.56 & 18.71 & 2.61 & $1>2$ \\
\hline Relationships & 24.27 & 3.49 & 23.03 & 2.65 & 16.20 & 1.37 & $1>3$ \\
\hline $\begin{array}{l}\text { Note. }{ }^{*} \mathrm{p}<.05 . \text { Th } \\
\text { illustrating signif }\end{array}$ & $\begin{array}{l}\text { numbers } \\
\text { ant diffe }\end{array}$ & $\begin{array}{l}\text { s in pare } \\
\text { erences } i\end{array}$ & $\begin{array}{l}\text { eses in c } \\
\text { e last co }\end{array}$ & $\begin{array}{l}\text { lumn } h \\
\text { umn tit }\end{array}$ & $\begin{array}{l}\text { refer to } \\
\text { Post ho }\end{array}$ & he num & used for \\
\hline
\end{tabular}

Table 4: Field Supervisors $(n=74)$ Ratings of Student Interns and Service-Learners

\begin{tabular}{|c|c|c|c|c|c|c|}
\hline Questions & $\begin{array}{c}\text { Unsatisfactory } \\
\%\end{array}$ & $\begin{array}{c}\text { Poor } \\
\%\end{array}$ & $\begin{array}{c}\text { Adequate } \\
\%\end{array}$ & $\begin{array}{c}\text { Good } \\
\%\end{array}$ & $\begin{array}{c}\text { Superior } \\
\%\end{array}$ & $\begin{array}{c}\text { Do Not } \\
\text { Know } \\
\%\end{array}$ \\
\hline \multicolumn{7}{|l|}{ Knowledge } \\
\hline $\begin{array}{l}\text { 1. Specific to job } \\
\text { assignment }\end{array}$ & 0 & 0 & 1 & 39 & 57 & 3 \\
\hline $\begin{array}{l}\text { 2. Understanding of } \\
\text { organization's policies }\end{array}$ & 0 & 0 & 5 & 44 & 44 & 7 \\
\hline $\begin{array}{l}\text { 3. Judgment in } \\
\text { performing tasks }\end{array}$ & 0 & 0 & 1 & 28 & 69 & 2 \\
\hline $\begin{array}{l}\text { 4. Overall ability to } \\
\text { learn }\end{array}$ & 0 & 0 & 1 & 22 & 75 & 2 \\
\hline $\begin{array}{l}\text { 5. Overall willingness } \\
\text { to learn } \\
\text { Skills }\end{array}$ & 0 & 0 & 0 & 24 & 76 & 0 \\
\hline
\end{tabular}




\begin{tabular}{|c|c|c|c|c|c|c|}
\hline $\begin{array}{l}\text { 1. Written } \\
\text { communication }\end{array}$ & 0 & 0 & 3 & 19 & 38 & 40 \\
\hline $\begin{array}{l}\text { 2. Ability to } \\
\text { communicate verbally }\end{array}$ & 0 & 0 & 3 & 25 & 69 & 3 \\
\hline $\begin{array}{l}\text { 3a. Ability to work with } \\
\text { colleagues }\end{array}$ & 0 & 0 & 3 & 26 & 67 & 4 \\
\hline $\begin{array}{l}\text { 3b. Ability to work with } \\
\text { clients }\end{array}$ & 0 & 0 & 0 & 27 & 68 & 5 \\
\hline $\begin{array}{l}\text { 4. Organization and use } \\
\text { of time }\end{array}$ & 0 & 1 & 3 & 32 & 58 & 6 \\
\hline $\begin{array}{l}\text { 5a. Technical skills - } \\
\text { rapport }\end{array}$ & 0 & 0 & 1 & 33 & 63 & 3 \\
\hline $\begin{array}{l}\text { 5b. Technical skills - } \\
\text { counseling }\end{array}$ & 0 & 0 & 0 & 23 & 44 & 33 \\
\hline $\begin{array}{l}\text { 5c. Technical skills - } \\
\text { information giving and } \\
\text { getting } \\
\text { Attitudes }\end{array}$ & 0 & 1 & 1 & 20 & 62 & 16 \\
\hline $\begin{array}{l}\text { 1. Desire for more } \\
\text { knowledge and skill }\end{array}$ & 0 & 1 & 6 & 24 & 69 & 0 \\
\hline $\begin{array}{l}\text { 2. Ability to take } \\
\text { supervision }\end{array}$ & 0 & 0 & 4 & 15 & 78 & 3 \\
\hline $\begin{array}{l}\text { 3. Relations with } \\
\text { co-workers }\end{array}$ & 0 & 0 & 0 & 21 & 67 & 12 \\
\hline 4. Dependability & 0 & 0 & 7 & 24 & 69 & 0 \\
\hline 5. Deportment & 0 & 0 & 3 & 18 & 61 & 18 \\
\hline
\end{tabular}

\subsection{Qualitative Analysis}

Data from field supervisors underwent an item-level analysis through which thematic patterns were identified and coded using a content analysis technique (Creswell, 2005). There was a total of 74 complete responses to open-ended questions. These responses were compared and analyzed using open and axial coding procedures to construct a conceptual framework. Open coding consisted of categorizing and naming the data according to theoretical concepts of experiential education (i.e., personal, professional, \& civic development) (Eyler \& Giles, 1999; Sweitzer \& King, 2009). Personal development refers to responses that reflect discipline knowledge, while professional development refers to responses that reflect career interests, and civic development refers to responses that reflect an understanding of racial disparities or social injustices in the community (Sweitzer \& King, 2009). Axial coding consisted of systematically analyzing the data using topical codes based on multicultural (i.e., awareness, knowledge, \& skills) (Howard-Hamilton, 2000; Sue \& Sue, 2003) and social justice (i.e., commitment to service \& social justice) models (Cipolle, 2010). Topical codes were further compared using the constant comparative method to match multicultural and social justice categories with experiential education themes. Two coders counted the number of responses and divided them by the number of total interviews and responses to obtain the percentages for each theme and category as shown in Table 5. Students acquired personal, civic, and professional skills through their participation in service activities.

Table 5: Post-Survey Data on Field Supervisor Views of Students

\begin{tabular}{|c|c|c|c|c|}
\hline$\%$ & Themes & $\%$ & Categories & Examples \\
\hline 100 & $\begin{array}{l}\text { Personal } \\
\text { Development }\end{array}$ & 98 & $\begin{array}{l}\text { Commitment } \\
\text { To Service }\end{array}$ & $\begin{array}{l}\text { Students learned about different disorders; Students practiced } \\
\text { behavior modification techniques and family therapy } \\
\text { interventions; Students worked with children who have special } \\
\text { needs and learned to assist them in the after-school program; } \\
\text { Student has worked with groups of children and provided } \\
\text { supports for ESL learners. }\end{array}$ \\
\hline 68 & $\begin{array}{l}\text { Civic } \\
\text { Development }\end{array}$ & 66 & $\begin{array}{l}\text { Multicultural } \\
\text { Awareness }\end{array}$ & $\begin{array}{l}\text { Students worked with different types of patients from children } \\
\text { to geriatric; Students worked with children with special needs in }\end{array}$ \\
\hline
\end{tabular}




\begin{tabular}{|c|c|c|c|c|}
\hline & & & & $\begin{array}{l}\text { two special education classrooms; Students worked with } \\
\text { individuals with different counseling needs. }\end{array}$ \\
\hline & & 65 & $\begin{array}{l}\text { Multicultural } \\
\text { Knowledge }\end{array}$ & $\begin{array}{l}\text { Students learned about different disorders and what techniques } \\
\text { to use with children diagnosed with different disorders; Students } \\
\text { learned strategies that support students who are struggling } \\
\text { readers. }\end{array}$ \\
\hline & & 49 & $\begin{array}{l}\text { Multicultural } \\
\text { Skills }\end{array}$ & $\begin{array}{l}\text { Students demonstrated strong interpersonal, empathetic, and } \\
\text { counseling/helping skills that are required for effective work in } \\
\text { treatment. Students interacted well with } \\
\text { children/clients/residents. }\end{array}$ \\
\hline 88 & $\begin{array}{l}\text { Professional } \\
\text { Development }\end{array}$ & 88 & $\begin{array}{l}\text { Interpersonal } \\
\text { Skills }\end{array}$ & $\begin{array}{l}\text { Students had excellent communication and time management } \\
\text { skills. Students were reliable, dependable, and flexible; Students } \\
\text { worked as a team or worked well with staff; Students } \\
\text { demonstrated limit setting skills with clients. }\end{array}$ \\
\hline & & 96 & $\begin{array}{l}\text { Commitment } \\
\text { to Social } \\
\text { Justice }\end{array}$ & $\begin{array}{l}\text { Students picked up information quickly and were very } \\
\text { professional. A perfect or excellent career choice. The student } \\
\text { was a leader in the classroom. She has been a huge help to the } \\
\text { children, particular the ESL learners. }\end{array}$ \\
\hline & & 38 & & Student interns hired at the agency. \\
\hline
\end{tabular}

\section{Discussion}

This study illuminates the value of experiential education in assisting students acquire a deeper understanding of social justice issues in the community. The first objective of this study was to measure differences in students' attitudes and skills among student interns, academic-based service-learners, and cultural-based service-learners from the beginning to the end of the semester. Students did not differ in scores at the beginning of the semester, but by the end of the term student interns had higher multicultural awareness and intercultural relationship scores and lower racial and civic attitude scores than did cultural-based service-learners. Student interns completed 200 hours of service in which they utilized helping skills with racially and economically diverse recipients diagnosed with a range of psychological, learning, and physical disorders at public schools, community-based counseling centers and physical therapy clinics. Exposure to extensive work with diverse recipients provided students with an opportunity to increase their multicultural awareness and develop intercultural relationships, which in turn, challenged them to rethink their racial assumptions of recipients and interests in service. These findings are consistent with a social justice perspective of service and the stages of the racial identity development model. (Boyle-Baise, Brown, Hsu, Jones, Prakash, Rausch, Vitols, \& Wahlquist, 2006; Conley \& Hamlin, 2009). Helms (1995) proposes that there needs to be a substantial amount a time for intercultural interactions to occur between Whites and Blacks so they can engage in a meaningful dialogue, obtain information that contradicts their racial precognitions, and change their colorblind assumptions to less racist views.

The combination of the course content and the service context also influence the development of student attitudes and skills. All student groups made reductions in their interest in advocacy efforts against institutional barriers, recognition of differences in their own views and those of recipients, and desire to continue to participate in service by the end of the semester, regardless if they were enrolled in a practicum or a service-learning course. Experiential teaching methods support the goals of social justice and multicultural education; however, students can fulfill service requirements and formulate colorblind views unless they are challenged to critically think about the diversity content in the service context (Boyle-Baise, 1998; Mitchell, 2010; Sperling, 2007).

Greater alignment between course content and service activities may explain observed differences in student attitudes and skills among the three groups. Student interns made increases in their post-service ratings of multicultural and problem-solving skills compared to academic-based service-learners, and they made improvements in their post-service ratings of multicultural knowledge compared to cultural-based service-learners. Cultural-based service-learners had higher ratings of their post-service social justice and diversity attitudes compared to academic-based service-learners. There are personal reasons that influence students to enroll in a diversity course. White racial identity theory explains how Whites are interested in learning about cultural differences and become aware of social injustices that result from White privilege through diversity coursework (Helms, 1995). Therefore, 
student cognitions and dispositions are related to student attitude-formation and skill-acquisition. Cultural-based service-learners were also required to examine their diversity knowledge and racial assumptions in the course. Students were required to analyze how their cognitions of race and class changed throughout the semester. In addition, cultural-based service-learners tutored and mentored diverse recipients and observed the limited resources associated with public schools located in inner-city neighborhoods. Students were required to connect service activities to the diversity content through written assignments. These assignments may have afforded students the opportunity to further examine their own knowledge and skills, thus contributing to their greater understanding of educational inequities for children of different class and racial groups and the realization of the skills they lack and need for effective work with children in educational settings, congruent on multicultural service-learning research (Boyle-Baise, 1998; Boyle-Baise, Bridgwaters, Brinson, Hiestand, Johnson, \& Wilson, 2007; Sperling, 2007).

The second objective was to measure differences in field supervisor ratings of student interns and service-learners. Field supervisors appraised student interns as having a better ability to form relationships with coworkers than service-learners. Student interns were juniors and seniors who spent a considerable amount of time at placement sites. It is possible that the amount of time is related to students' ability to establish relationships with professionals. The amount of time devoted to providing service is a key element in fostering intercultural interactions between students and recipients that counter preconceived assumptions and improve their understanding of social problems (Helms, 1995; Rosner-Salazar, 2003). Field supervisors rated student interns similarly to service-learners and appraised them as having strong written communication, interpersonal, and time management skills.

Field supervisors further suggest that students acquire discipline knowledge (i.e., personal development), develop social responsibility (i.e., civic development), and make career choices (i.e., professional development) through participation in service activities. Students conducted assessments, facilitated group and individual sessions, and implemented therapeutic activities with children and adults diagnosed with various psychological and physical disorders and these service-activities may have contributed to their deeper understanding of the psychological content. Most field supervisors felt that service activities helped students formulate career goals and were better prepared for future work, and almost half of them also thought that students were sensitive to recipients' cultural and developmental needs, congruent with both student interns' reports and previous studies (Aldas et al., 2010; Eyler \& Giles, 1999).

Overall, the findings from this study point to experiential education as a potentially transformative pedagogy that assists students to achieve social justice and multicultural education goals, but only when these are explicit course objectives and outcomes. Students engage in service activities with diverse recipients, and for many of them, this is an eye-opening experience. There is the potential for students to leave this experience with little understanding of the systematic nature of racial and economic disparities unless diversity and social justice issues are addressed in the course and service context (Boyle-Baise, 1998; Mitchell, 2010; Sperling, 2007).

The current study adds to the research on experiential education, although we accept the reality that it is impossible to generalize our findings beyond the sample surveyed. The student population in this study is demographically homogenous. Student participants were predominantly White and female, came from middle-class backgrounds, and usually were the first-generation to attend a four-year college. There probably is internal validity limitations associated with service activities with recipients at our placement sites. Student interns worked with children and adults diagnosed with various psychological and physical disabilities at community-based centers and physical therapy clinics, while service-learners worked with African American and Latino children in public schools located in inner-city neighborhoods. The uniqueness of the service experiences makes replication difficult. Additional surveys were added to collect feedback from field supervisors during the second semester of the academic year. There is the potential for Type II errors to be associated with observed differences in field supervisor ratings of attitudes and skills for student interns and academic-based service-learners that were detected in this study. The use of multiple data sources does not prevent participant bias in written materials. There is the potential for testing and social desirability effects to be associated with participant responses that were collected with surveys and interviews at different points in time. A triangulation multi-method qualitative and quantitative approach with random samples of male and female students is needed to generalize and expand on the findings from the present study. 


\section{References}

Aldas, T., Crispo, V., Johnson, N., \& Price, T.A. (2010). Learning by doing: The Wagner plan from classroom to career. Peer Review, 12(4), 24-28.

American Psychological Association Committee on Accreditation (2005). Guidelines and principles for accreditation programs in professional psychology. Retrieved from http://www.apa.org/ed/gp2000.html

Association for Experiential Education. (2011). How it works in higher education. Retrieved from http://www.aee.org/applications/highered/\#commonthemes

Astin, A. W., \& Sax, L. J. (1998). How undergraduates are affected by service participation. Journal of College Student Development, 39(3), 251-263.

Boyle-Baise, M., Bridgwaters, B., Brinson, L., Hiestand, N., Johnson, B., \& Wilson, O. (2007). Improving the human condition: Leadership for justice-oriented service- learning. Equity and Excellence in Education, 40, 113-122. http://dx.doi.org/10.1080/10665680601152808

Boyle-Baise, M., Brown, R., Hsu, M., Jones, D., Prakash, A., Rausch, M., Vitols, S., \& Wahlquist, Z. (2006). Learning service or service learning: Enabling the civic. International Journal of Teaching and Learning in Higher Education, 18(1), 17-26.

Boyle-Baise, M., \& Langford, J. (2004). There are children here: Service-learning for social justice. Equity and Excellence in Education, 37, 55-66. http://dx.doi.org/10.1080/10665680490422115

Boyle-Baise, M. (1998). Community service learning for multicultural education: An exploratory study with preservice teachers. Equity and Excellence in Education, 31(2), 52-60. http://dx.doi.org/10.1080/1066568980310207

Cipolle, S. B. (2010). Service-learning and social justice: Engaging students in social change. Lanham, Maryland: Rowman and Littlefield.

Conley, P. A., \& Hamlin, M. L. (2009). Justice-Learning: Exploring the efficacy with low-income, first-generation college students. Michigan Journal of Community Service, 16(1), 47-58.

Creswell, J. W. (2005). Educational research, 2nd edition. Upper Saddle River, NJ: Pearson Prentice Hall.

Dunlap, M., Scoggin, J., Green, P., \& Davi, A. (2007). White students' experience of privilege and socioeconomic disparities: Toward a theoretical model. Michigan Journal of Community Service, 13(2), 19-30.

Eyer, J. (2002). Reflection: Linking service and learning - linking students and communities. Journal of Social Issues, 58(3), 517-534. http://dx.doi.org/10.1111/1540-4560.00274

Eyler, J. S., \& Giles, D. E. (1999). Where's the learning in service-learning? San Francisco: Jossey-Bass.

Green, A. E. (2001). "But you aren't white:" Racial perspectives and service learning. Michigan Journal of Community Service Learning, 8(1), 18-26.

Helms, J. E. (1995). An update of Helms's White and People of Color racial identity models. In J. G. Ponterotto, J. M. Casas, L. A., Suzuki, \& C. M. Alexander (Eds.), Handbook of multicultural counseling (pp. 181-198). Thousand Oaks, CA: Sage.

Howard-Hamilton, M. (2000). Programming for multicultural competencies. New Directions for Student Services, 90, 67-78. http://dx.doi.org/10.1002/ss.9006

McConahay, J. B. (1986). Modern racism, ambivalence, and the Modern Racism Scale. In J. F. Dovidio \& S. L. Gaertner (Eds.), Prejudice, discrimination, and racism (pp. 91-126). San Diego, California: Academic Press.

McKay, V. C., \& Estrella, J. (2008). First-generation student success: The role of faculty interaction in service learning courses. Communication Education, 57(3), 356-372. http://dx.doi.org/10.1080/03634520801966123

Mitchell, T.D. (2010). Challenges and possibilities: linking social justice and student learning. Michigan Journal of Community Service Learning, 17(1), 94-97.

Moely, B. E., Mercer, S. H., Ilustre, V., Miron, D., \& McFarland, M. (2002b). Psychometric properties and correlates of the civic attitudes and skills questionnaire (CASQ): A measure of student's attitudes related to service-learning. Michigan Journal of Community Service Learning, 8(2), 15-26.

Rosner-Salazar, T.A. (2003). Multicultural service-learning and community-based research as a model approach to promote social justice. Social Justice, 30(4), 64-76. 
Sigmon, R. L. (1996). The problem of definitions in service-learning. In R.L. Sigmon and colleagues (Eds.), Journey to service-learning (pp.9-12). Washington: DC: The Council of Independent Colleges.

Sodowsky, G. R., Taffe, R. C., Gutkin, T. B., \& Wise, S. L. (1994). Development of the multicultural counseling inventory: A self-report measure of multicultural competencies. Journal of Counseling Psychology, 41(2), 137-148. http://dx.doi.org/10.1037/0022-0167.41.2.137

Sperling, R. (2007). Service-learning as a method of teaching multiculturalism to White college students. Journal of Latinos and Education, 6(4), 309-322. http://dx.doi.org/10.1080/15348430701473454

Sue, D. W., \& Sue, D. (2003). Counseling the culturally diverse: Theory and practice (4th edition). New York, NY: John Wiley and Sons.

Sweitzer, H.F., \& King, M.A. (2009). The successful internship: Personal, professional, and civic development. Belmont, CA: Brooks/Cole.

Yeh, T. L. (2010). Service-learning and persistence of low-income, first-generation college students: An exploratory study. Michigan Journal of Community Service, 16(2), 50-65. 